\title{
Levels of replacing corn by cassava starch on performance and carcass characteristics of bulls finished in feedlot
}

\author{
Substituição do milho pelo resíduo da fecularia de mandioca no \\ desempenho e nas características de carcaça de bovinos terminados \\ em confinamento
}

\author{
Paulo Henrique Moura Dian ${ }^{1}$; Ivanor Nunes do Prado ${ }^{3 *}$; \\ Maribel Velandia Valero $;$; Polyana Pizzi Rotta ${ }^{5}$; Rodolpho Martin do Prado \\ Robério Rodrigues Silva ${ }^{7}$; Liandra Maria Abaker Bertipaglia ${ }^{2}$
}

\begin{abstract}
This work was carried out to study the effects of replacing corn by different levels of cassava starch ( 0 ; $12.5 ; 22.8$ and $32.7 \%$ ) on performance and carcass characteristics of bulls finished in feedlot. Thirtytwo crossbred bulls ( $1 / 2$ Aberdeen Angus vs. $1 / 2$ Nellore) with 18 months old and $380+24 \mathrm{~kg}$ live weight were used in a completely randomized experimental design with four treatments and eight replications. The experiment was realized during 56 days with 14 days for adaptation. The complete diets [roughage (cottonseed hulls) + concentrate (corn, soybean meal and cassava starch)] were given at 8 am and at $4 \mathrm{pm}$ to bulls. It was analyzed the initial weight (IW), final weight (FW), average daily gain (ADG), dry matter intake (DMI), feed conversion (FC), hot carcass dressing (HCD), fat thickness (FAT), Longissimus muscle area (LMA), leg length (LL) and cushion thickness (CT). The IW, FW, ADG, FC, HCW, HCD, FT, LMA, LL and CT did not present difference $(\mathrm{P}>0.05)$ among levels of replacing corn by cassava starch. The results obtained on performance and carcass traits using cassava starch by-products as a replacement for corn can be considered satisfactory.
\end{abstract}

Key words: Beef cattle, cassava, cattle performance, cotton hulls, feedlot

\section{Resumo}

Objetivou-se com este trabalho avaliar o efeito do nível de substituição $(0 ; 12,5 ; 22,8$ e 32,7\%) do milho pelo resíduo de fecularia de mandioca sobre o desempenho e características de carcaça de bovinos em confinamento. Trinta e dois machos inteiros mestiços ( $1 / 2$ Aberdeen Angus vs. 1/2 Nelore) com 18 meses

1 Professor do Centro Regional Universitário de Espírito Santo do Pinhal e do Centro Estadual de Educação Tecnológica Paula Souza, na ETEC DR. Carolino da Motta \& Silva - Espírito Santo do Pinhal. E-mail: phmdian@hotmail.com

2 Doutorado em Zootecnia da Faculdade de Ciências Agrárias e Veterinárias, UNESP/Jaboticabal. Professor Universitário no curso de Medicina Veterinária e Agronomia e no mestrado Stricto sensu, área de concentração em Produção Animal, na Universidade Camilo Castelo Branco (UNICASTELO), Descalvado-SP. E-mail: lmabertipaglia@hotmail.com

3 Pós-Doutorado em Zootecnia pelo Institut National dAgronomie - Paris-Grighon. Professor Titular da cadeira de Bovinocultura de Corte da Universidade Estadual de Maringá. E-mail: imprado@uem.br

4 Mestranda em Zootecnia pela Universidade Estadual de Maringá. E-mail: maribelvelandia@hotmail.com

Aluna do curso de Zootecnia da Universidade Estadual de Maringá. E-mail: polyanazootecnia@hotmail.com

Graduado pela Universidade Estadual de Maringá. E-mail: fran6@hotmail.com

7 Doutorado pela Universidade Estadual de Maringá. Professor Adjunto da Universidade Estadual do Sudoeste da Bahia. E-mail: rrsilva@pq.cnpq.br

* Autor para correspondência 
de idade e $380 \pm 24 \mathrm{~kg}$ de peso vivo foram utilizados em delineamento experimental inteiramente casualizado, com quatro tratamentos e oito repetições. O experimento foi desenvolvido durante 56 dias com 14 dias de adaptação. As rações completas [volumoso (casca de algodão) + concentrado (milho, farelo de soja e resíduo desidratado de fecularia de mandioca)] foram fornecidas às $8 \mathrm{~h}$ e $16 \mathrm{~h}$ aos animais. Foi analisado o peso inicial (PI), peso final (PF) ganho médio diário (GMD), ingestão de matéria seca (IMS), conversão alimentar da matéria seca (CAMS), peso de carcaça quente (PCQ), rendimento de carcaça quente (RCQ), espessura de gordura de cobertura (EGC), área de olho de lombo (AOL), comprimento de perna (CP) e espessura de coxão (EC). Os resultados observados para PI, PF, GMD, CAMS, RCQ, EGC, AOL, CP e EC não apresentaram diferenças $(\mathrm{P}>0,05)$ entre os tratamentos. Os resultados obtidos para desempenho e características de carcaça foram satisfatórios.

Palavras-chave: Carne bovina, casca de algodão, confinamento, desempenho animal, mandioca

\section{Introduction}

As a result of price increases in conventional feedstuffs for ruminants, increased interest has been observed in other, alternative, types of feed for these animals (PRADO et al., 1995; D'OLIVEIRA et al., 1997). Nevertheless, a few factors should be highlighted regarding the use of these products: availability and quality, in order to enable their use in animal feeding. In addition to these factors, attention must be given to the cost of these feedstuffs. Some by-products of manufacturing, such as those from the production of cassava flour (cassava scrapings and hulls) could be alternative energy sources in ruminant feeding (MARQUES et al., 2000; PRADO et al., 2000). There are also cassava starch by-products (the result of milling cassava in order to extract the starch), which is dried and used in ruminant feeding (ABRAHÃO et al., 2005; 2006). The results of cattle performance with the use of cassava by-products were similar to the conventional sources used to finish cattle in feedlot (MARQUES et al., 2000; PRADO et al., 2000; JORGE et al., 2002; ABRAHÃO et al., 2006).

Cottonseed hull is a by-product obtained after the oil extraction process, prior to the flaking process that produces cottonseed meal. It features a variable chemical composition, due to the many different processes available; it can feature varying amounts of linter in the hull and can be used an alternative roughage source (KAZAMA et al., 2008). However, few studies have been performed on its efficiency in ruminant feeding. This residue features inferior nutritional characteristics when compared to the more traditional roughage sources used in feedlot. Cottonseed hulls are used in the diets of cattle finished in feedlot in other countries, and is in some situations the main source of roughage available to the animals (HALE et al., 1969; VERNLUND et al., 1980). As a result of its ease of handling, low cost (VERNLUND et al., 1980), availability (HSU et al., 1987) and acceptance (ROGERS et al., 2002) cottonseed hulls have been used for animals in feedlot (KAZAMA et al., 2008).

There are some factors that are responsible for the carcass quality. Hot carcass weight, hot carcass dressing, leg length, cushion thickness, Longissimus muscle area, fat thickness are characteristics responsible by carcass quality (MOREIRA et al., 2003; MACEDO et al., 2008; PRADO et al., 2008a; b; c; d; MAGGIONI et al., 2009; PRADO et al., 2009a; b; c; ROTTA et al., 2009a; b).

The objective of this study was to evaluate animal performance, feed intake, feed conversion and carcass traits of crossbred bulls that received four diets with varying levels of corn replacement $(0 ; 12.5 ; 22.8$ and $32.7 \%$ ) by dehydrated cassava by-products starch using cottonseed hulls as roughage.

\section{Materials and methods}

\section{Animal management and sampling}

The State University of Maringá animal care and ethics committee approved the use of bulls in this study (CIOMS/OMS, 1985). 
This study was carried out at the Experimental Farm of Iguatemi, Paraná. The analyses of diets were realized in Laboratory of Feed Analyses and Animal Nutrition of State University of Maringá. Thirty-two crossbred bulls ( $1 / 2$ Aberdeen Angus vs. $1 / 2$ Nellore) with an initial age of 18 months were used. The initial live weigh of these animals were $380 \pm 24 \mathrm{~kg}$. The animals were kept separate in individual pens $\left(10 \mathrm{~m}^{2}\right.$ for each animal), and fed twice a day. They were given access to a diet formulated to meet requirements for fattening beef cattle for a gain of $1.50 \mathrm{~kg}$ /day (NRC, 1996). Four diets were formulated to attend the requirements of the animals.

The complete diets [roughage (cottonseed hulls) + concentrate (corn, soybean meal and cassava starch)] were given at 8 am and at $4 \mathrm{pm}$ to animals. Water was given ad libitum.

Dry matter (DM), crude protein $(\mathrm{CP})$, organic matter (OM), ash, neutral detergent fiber (NDF), acid detergent fiber (ADF), calcium (C) and phosphorus (P) were analyzed, according to Silva and Queiroz (2002).

Composition of the ingredients $(\% \mathrm{DM})$ and chemical composition of the ingredients $(\% \mathrm{DM})$ are presented in Table 1 and 2, respectively.

It was analyzed the initial weight (IW), final weight (FW), average daily gain (ADG), dry matter intake (DMI), feed conversion ratio (FCR), hot carcass weight (HCW) hot carcass dressing (HCD), fat thickness (FAT), Longissimus muscle area (LMA), leg length (LEL) and cushion thickness (CUT).

Table 1. Composition of the ingredients (\%/DM).

\begin{tabular}{lcccc}
\hline Ingredients & Levels of replacing & & \\
\cline { 2 - 5 } & $\mathrm{R} 0.0$ & $\mathrm{R} 12.5$ & $\mathrm{R} 22.8$ & $\mathrm{R} 32.7$ \\
\hline Ground corn grain & 43.2 & 32.0 & 22.5 & 12.5 \\
Cassava starch & 0.00 & 12.5 & 22.8 & 32.7 \\
Soybean meal & 7.40 & 9.03 & 11.7 & 13.3 \\
Mineral salt & 0.70 & 0.70 & 0.70 & 0.70 \\
Phosphate dicalcium & 0.00 & 0.05 & 0.11 & 0.19 \\
Limestone & 0.68 & 0.67 & 0.59 & 0.53 \\
Lasalocid & 0.02 & 0.02 & 0.02 & 0.02 \\
Cottonseed hulls & 48.0 & 45.0 & 41.7 & 40.0 \\
\hline Total & 100 & 100 & 100 & 100 \\
\hline
\end{tabular}

Table 2. Chemical composition of ingredients in diets (\%/DM).

\begin{tabular}{lccccccccc}
\hline Ingredients & $\mathrm{DM}^{1}$ & $\mathrm{GE}^{2 \#}$ & $\mathrm{CP}^{3}$ & $\mathrm{OM}^{4}$ & $\mathrm{MM}^{5}$ & $\mathrm{NDF}^{6}$ & $\mathrm{ADF}^{7}$ & $\mathrm{Ca}^{8}$ & $\mathrm{P}^{9}$ \\
Ground corn graind & 89.1 & 4.32 & 8.00 & 99.0 & 1.04 & 12.6 & 3.11 & 0.03 & 0.32 \\
Cassava starch & 88.9 & 4.06 & 1.93 & 98.3 & 1.67 & 32.8 & 24.9 & 0.40 & 0.10 \\
Soybean meal & 88.6 & 4.71 & 50.8 & 95.1 & 4.91 & 15.0 & 11.1 & 0.46 & 0.73 \\
Cottonseed hulls & 89.2 & 4.58 & 5.55 & 96.7 & 3.30 & 90.2 & 67.7 & 0.20 & 0.10 \\
Mineral salt & 98.7 & - & - & 10.7 & 89.3 & - & - & 17.4 & 0.30 \\
Phosphate dicalcium & 98.2 & - & - & 8.34 & 91.7 & - & - & 23.5 & 18.0 \\
Limestone & 99.9 & - & - & 0.46 & 99.5 & - & - & 34.0 & - \\
\hline Levels of replacing & $\mathrm{DM}^{1}$ & $\mathrm{GE}^{2 \#}$ & $\mathrm{CP}^{3}$ & $\mathrm{MO}^{4}$ & $\mathrm{MM}^{5}$ & $\mathrm{NDF}^{6}$ & $\mathrm{ADF}^{7}$ & $\mathrm{Ca}^{8}$ & $\mathrm{P}^{9}$ \\
R0.0 & 89.2 & 4.41 & 9.88 & 96.2 & 3.81 & 49.9 & 34.7 & 0.50 & 0.24 \\
R12.5 & 89.1 & 4.37 & 9.65 & 96.1 & 3.91 & 50.1 & 35.6 & 0.55 & 0.24 \\
R22.8 & 89.2 & 4.34 & 10.0 & 96.0 & 3.97 & 49.6 & 35.9 & 0.58 & 0.24 \\
R32.7 & 89.2 & 4.31 & 10.0 & 95.9 & 4.09 & 50.4 & 37.1 & 0.62 & 0.25
\end{tabular}

${ }^{\#} \mathrm{Mcal} / \mathrm{kg}$ of DM. ${ }^{1}$ Dry matter, ${ }^{2} \mathrm{Gross}$ energy, ${ }^{3} \mathrm{Crude}$ protein, ${ }^{4}$ Organic matter, ${ }^{5}$ Mineral matter, ${ }^{6}$ Neutral detergent fiber, ${ }^{7}$ Acid detergent fiber, ${ }^{8} \mathrm{Calcium},{ }^{9}$ Phospphorum. 
The bulls were weighed in the beginning of the study and every 28 days, and on the day before slaughter, after 12-hour fasting. The duration of this experiment was of 56 days with 14 days for adaptation. The weightings were realized during the morning, animals were in fasting with solids feed.

\section{Carcass characteristics}

The animals were slaughtered at a commercial slaughterhouse in Maringá, Paraná according to industrial practices in Brazil. Following slaughter, the carcasses were identified and chilled for $24 \mathrm{~h}$ at $4^{\circ} \mathrm{C}$. After chilling, the right part of the carcass was used to determine the quantitative characteristics. Twenty-four hours later, Longissimus muscle (LM) samples were taken by a complete cross-section between the $12^{\text {th }}$ and $13^{\text {th }}$ ribs. The fat thickness was discarded and the muscle portion was frozen at $-20^{\circ} \mathrm{C}$ for further analyses.

Hot carcass weight $(\mathrm{HCW})$ : It was determined before chilling.

Hot carcass dressing: The percentage of individual animal dressing was defined by the ratio of hot carcass weight to live weight determined 14 hours before.

Fat thickness (FAT): It was taken by a caliper averaging three points between the $12^{\text {th }}$ and $13^{\text {th }}$ ribs on the LM.

Longissimus muscle area (LMA): The right part of the carcass was measured after a cross-section cut was made between the $12^{\text {th }}$ and $13^{\text {th }}$ ribs using a compensating planimeter, which measures the areas of objects with irregular shapes.

Leg length (LEL): It was evaluated using a wood compass with metallic edges that measures the distance from the anterior border of the pubis bone to a middle point at the tarsus bone.
Cushion thickness (CUT): It was taken by a wood compass with metallic edges that measure the distance between the lateral face and the median at the superior part of the cushion.

\section{Experimental design and statistical analysis}

The data set were submitted to the analysis of variance and regression by using the SAS software (SAS, 2000). The ANOVA followed the model: $\mathrm{Y}_{\mathrm{ijk}}=\mu+\mathrm{T}_{\mathrm{i}}+\mathrm{e}_{\mathrm{ijk}}$ in which $\mathrm{Y}_{\mathrm{ijk}}$ were the individual observations in $\mathrm{T}_{\mathrm{i}}$ which were the treatment effects $\mu$ were the constant, and $\mathrm{e}_{\mathrm{ijk}}$ were the error terms. The coefficients of determination were calculated by the ratio SSR/SST and the F test at $5 \%$ of probability were used to identify significant statistical models.

\section{Results and Discussion}

No difference was observed $(\mathrm{P}>0.05)$ for initial weight (IW), final weight (FW), average daily gain (ADG) and feed conversion (FC) among the four different treatments (Table 3). However, dry matter intake (kg/day) and dry mater intake per $100 \mathrm{~kg}$ of live weight (DMI/LW) showed a linear reduction $(\mathrm{P}<0.05)$, with an increase in the levels of cassava starch by-products as replacements for corn.

Theaveragefinalweight $(498 \mathrm{~kg})$ canbeconsidered adequate for the finishing and commercialization of crossbred cattle (F1 - 1/2 Nellore vs. 1/2 Angus) finished in feedlot fed with high density diet energy. The same group of researchers (ARICETTI et al., 2008; PRADO et al., 2008a; b; c) observed similar final weights in crossbred cattle with similar breeds and age as those in this experiment and finished under high density diets energy. 
Table 3. Replacement levels of corn by dehydrated start cassava by-products on initial weight (IW), final weight (FW), average daily gain (ADG), dry matter intake (DMI), dry matter intake /live weight (DMI/LW) and feed conversion (FC).

\begin{tabular}{|c|c|c|c|c|c|c|c|}
\hline \multirow{2}{*}{ Parameters } & \multicolumn{4}{|c|}{ Levels of replacing } & \multirow{2}{*}{ Mean } & \multirow[b]{2}{*}{$\mathrm{r}^{2}$} & \multirow{2}{*}{$\mathrm{CV}^{1}, \%$} \\
\hline & $\mathrm{R} 0.0$ & $\mathrm{R} 12.5$ & $\mathrm{R} 22.8$ & R32.7 & & & \\
\hline ILW, kg & 380 & 378 & 383 & 381 & $\hat{\mathrm{Y}}=381$ & & 9.48 \\
\hline FLW,kg & 496 & 498 & 510 & 486 & $\hat{Y}=498$ & & 8.34 \\
\hline $\mathrm{ADG}, \mathrm{kg} /$ day & 1.99 & 2.05 & 2.17 & 1.93 & $\hat{\mathrm{Y}}=2.04$ & & 14.4 \\
\hline DMI, kg/day & 13.6 & 12.4 & 12.5 & 10.1 & $\hat{\mathrm{Y}}=12.2-1.05 \mathrm{x}$ & 0.87 & 7.63 \\
\hline DMI/LW, \% & 3.10 & 2.84 & 2.77 & 2.33 & $\hat{\mathrm{Y}}=2.76-0.21 \mathrm{x}$ & 0.92 & 5.78 \\
\hline $\mathrm{FC}, \mathrm{kg} / \mathrm{kg} \mathrm{LW}$ & 6.96 & 6.12 & 5.79 & 6.06 & $\hat{\mathrm{Y}}=6.23$ & & 18.8 \\
\hline
\end{tabular}

${ }^{1}$ Coefficient of variation.

On the other hand, the observed average daily weight gain $(2.03 \mathrm{~kg})$ is above the weight gains observed in cattle with similar genetic groups and age as those in this experiment and finished in feedlot or in high-quality pasture systems (ARICETTI et al., 2008; PRADO et al., 2008a; b; c; ROTTA et al., 2009a; b). This elevated average daily weight gain could be explained by the good adaptation of animals in feedlot, high heterosis (F1), short feedlot period (56 days) and high energy density in the diet ( $55 \%$ concentrate and $45 \%$ roughage). In reality, the highest heterosis rate $(100 \%)$ is observed in the first generation to undergo industrial crossbreeding (Bos indicus vs. Bos taurus). Likewise, the short feedlot period (56 days) could have favored the effect of compensatory gains, which occurs during the first few weeks of confinement under high density diets energy. The high rate of concentrate $(55.0 \%)$ also contributed to the high average daily weight gain.

The linear reduction observed in dry matter intake with increase in cassava residue, both in absolute values $(\mathrm{kg} / \mathrm{day})$ or relative values ( $\mathrm{kg}$ dry matter/ per $100 \mathrm{~kg}$ of live weight) can be explained by the increase in cassava by-products in cattle diet. Marques et al. (2000) and Abrahão et al. (2006) observed that the inclusion of cassava byproducts in cattle diets reduces feed intake. These authors concluded that the reduction in feed intake is caused by the rough aspect of cassava by- products, which makes chewing and swallowing more difficult. During the experimental period, diet selectivity by the animals was observed. In some cases, there was a higher ratio of leftovers from concentrate than roughage in diets containing higher levels of replacement of corn by dehydrated cassava residue $(32.7 \%)$. The reduction in DMI as a function of the increase in the replacement of corn by dehydrated cassava residue can be partly attributed to the lesser palatability of the residue as compared to corn. According to Hill (1970), when entering the mouth, this feedstuff stimulates saliva secretion, which is attributed to the reflex stimulus of the salivary glands, though the mouth receptors. In general, traditional feedstuffs used in animal feeding cause secretion of saliva that is rich in mucin and enzymes, which facilitated swallowing, whereas highly dehydrated feedstuffs cause a considerable flow of mucin-deficient saliva. Consequently, less saliva with high mucin levels is secreted, possibly leading to swallowing deficiencies and decreased intake. The high DMI levels found, regardless of treatment (average $2.75 \%$ of LW), may be related to the type of roughage used, meaning cottonseed hulls. Several authors, after including increasing levels of cottonseed meal $(0,10,20$ and $30 \%)$ in the diets of cattle, reported a linear increase in DM intake (BARTLE et al., 1994; MAGALHÃES et al., 2005; GU and MOSS, 2006). Likewise, OLTJEN 
et al. (1977) while evaluating the performance of calves fed different by-products (chopped oat straw, whole corn plant and cottonseed hulls), observed higher DM intake for animals that had been fed the hulls $(3.10 \%$ of LW).

Feed conversion ratio of dry matter was 6.22 $\mathrm{kg}$ per $\mathrm{kg}$ of live weight gain. This conversion can be considered excellent and is better than the conversions observed for animals finished in feedlot (MARQUES et al., 2000; ABRAHÃO et al., 2006; KAZAMA et al., 2008). Good feed conversion ratio may be related to the age and genetic quality of the animals, to the high average daily weight gain, and to the elevated energy density of the diet. Generally, feed conversion ratio is improved when weight gain increases, as FC is the ratio between intake and weight gain, and feature a positive correlation with average daily weight gain.

Hot carcass weight (HCW), hot carcass dressing (HCD), fat thickness (FAT), leg length (LEL) and cushion thickness (CUT) were similar $(\mathrm{P}>0.05)$ among treatments (Table 4).

Table 4. Replacement levels of corn by dehydrated start cassava by-products on hot carcass weight (HCW), hot carcass dressing (HCD), fat thickness (FAT), Longissimus muscle area (LMA), leg length (LEL) and cushion thickness (CUT).

\begin{tabular}{lcccccc}
\hline \multirow{2}{*}{ Parameters } & \multicolumn{4}{c}{ Levels of replacing } & \multirow{2}{*}{ Mean } & \multirow{2}{*}{ CV $^{1}, \%$} \\
\cline { 2 - 5 } & R0.0 & R12.5 & R22.8 & R32.7 & & \\
\hline HCW, kg & 267 & 272 & 276 & 269 & $\hat{\mathrm{Y}}=271$ & 8.85 \\
HCD, \% & 54.0 & 54.6 & 54.1 & 55.1 & $\hat{\mathrm{Y}}=54.5$ & 3.31 \\
FAT, mm & 4.06 & 4.34 & 4.63 & 4.75 & $\hat{\mathrm{Y}}=4.44$ & 18.5 \\
LMA, cm & 80.0 & 78.9 & 88.1 & 86.8 & $\hat{\mathrm{Y}}=83.5$ & 12.6 \\
LEL, cm & 72.6 & 73.2 & 73.5 & 72.6 & $\hat{\mathrm{Y}}=73.0$ & 2.49 \\
CUT, cm & 24.6 & 25.0 & 25.7 & 25.6 & $\hat{\mathrm{Y}}=25.2$ & 8.45 \\
\hline
\end{tabular}

${ }^{1}$ Coefficient of variation.

The high hot carcass weight observed $(271 \mathrm{~kg})$ is due the high slaughter weight $(498 \mathrm{~kg})$. In reality, hot carcass weight is partly determined by slaughter weight and carcass dressing. However, some studies using crossbred animals finished in feedlot have presented similar or even higher slaughter weights (MOREIRA et al., 2003; ABRAHÃO et al., 2005).

Average HCD observed in all four treatments was $54.4 \%$. HCD can be considered satisfactory for the crossbred animal finishing system (feedlot). Likewise, this result was similar to those observed by the same research group in several studies using crossbred animals finished in feedlot (MARQUES et al., 2000; ABRAHÃO et al., 2006; KAZAMA et al., 2008).
The average fat thickness (FAT) of $4.45 \mathrm{~mm}$ for all four treatments is in accordance with the minimum desired by the beef industry in Brazil, which can vary from 3 to $6 \mathrm{~mm}$. The observed 4.45 mm FAT is related to the slaughter weight of the animals. In general, FAT is normally higher when the animals are slaughtered at a higher live weight. Furthermore, similar FAT was recorded under similar conditions of finishing systems for animals originated from industrial crossbreeding (PRADO et al., 2008a, b).

The average Longissimus muscle area (LMA) $\left(87.0 \mathrm{~cm}^{2}\right)$ observed indicated that the animals were well finished at slaughter time and featured adequate musculature for commercialization, meeting the 
requirements of the Brazilian beef market. The observed LMA was similar to the data obtained by researchers working with animals originated from industrial crossbreeding and finished in feedlot (PRADO et al., 2008a, b).

Leg length $(73.0 \mathrm{~cm})$ and cushion thickness $(25.2$ $\mathrm{cm}$ ) are close to the values observed by other authors working with crossbred animals finished in feedlot (ABRAHÃO et al., 2006; PRADO et al., 2008a, b). In general, diet has little effect on these traits.

\section{Conclusions}

The results obtained for performance and carcass traits using cassava starch by-products as a replacement for corn can be considered satisfactory. The determinant factor to be applied is the market price for corn and cassava starch by-products, as well as the availability of the latter, which is an industrial by-products and is not available in all regions. As such, in regions where there is wide availability of cassava starch residue, it can be used as a replacement for corn $(32 \% / \mathrm{DM})$, as it is generally cheaper and does not present adverse effects for animal performance.

\section{Acknowledgments}

This study was supported by the Araucaria Foundation and Brazilian Council for Research and Technological Development (CNPq).

\section{References}

ABRAHÃO, J. J. S.; PRADO, I. N.; MARQUES, J. A.; PEROTTO, D.; LUGÃO, S. M. B. Effects of replacing corn with dry cassava by-product on production of feedlot crossbred heifers Brazilian Journal of Animal Science, Viçosa, v. 35, n. 2, p. 512-518, 2006.

ABRAHÃO, J. J. S.; PRADO, I. N.; PEROTTO, D.; MOLETTA, J. L. Effects of replacing corn with increasing levels of cassava starch by-products on carcass characteristics and meat for young bulls Brazilian Journal of Animal Science, Viçosa, v. 34, n. 5, p. 16401650, 2005.
ARICETTI, J. A.; ROTTA, P. P.; PRADO, R. M.; PEROTTO, D.; MOLETTA, J. L.; MATSUSHITA, M.; PRADO, I. N. Carcass characteristics, chemical composition and fatty acid profile of the Longissimus muscle of bulls and steers finished in a pasture system. Asian-Australasian Journal of Animal Sciences, Korea, v. 21, n. 10, p. 1.441-1.448, 2008.

BARTLE, S. J.; PRESTON, R. L.; MILLER, M. F. Dietary energy source and density: effects of roughage source, roughage equivalent, tallow level and steer type on feedlot performance and carcass characteristics. Journal of Animal Science, Savoy, v. 72, n. 8, p. 19431953, 1994.

CIOMS/OMS. Council for International Organizations of Medical Sciences. WHO Distribution and Sales Service, 1211 Geneva 27, Switzerland, International Guiding Principles for Biomedical Research Involving Animals, 1985.

D’OLIVEIRA, P. S.; PRADO, I. N.; SANTOS, G. T.; ZEOULA, L. M.; DAMASCENO, J. C.; MARTINS, E. N.; SAKAGUTI, E. S. Efeito da substituição do farelo de soja pelo farelo de canola sobre o desempenho de novilhas Nelores confinadas confinamento. Brazilian Journal of Animal Science, Viçosa, v. 26, n. 3, p. 568-574, 1997.

GU, S. C.; MOSS, B. R. Lactation performance of cows fed low and high rumen undegradable protein diets with varying levels of cottonseed hulls and protein. Journal of Dairy Science, Savoy, v. 79, p. 152, 1996. Supplement 1.

HALE, W. H.; LAMBETH, C.; THEURER, B.; RAY, D. E. Digestibility and utilization of cottonseed hulls by cattle. Journal of Animal Science, Savoy, v. 29, n. 5, p. 773-776, 1969.

HILL, K. J. Salivary and gastry secretions, in dukes physiology of domestic animals. Ithaca, New York: Comstock Publishing Associates, 1970. 370 p.

HSU, J. T.; FAULKNER, D. B.; GARLEB, K. A.; BARCLAY, R. A.; FAHEY, G. C; BERGER, L. L. Evaluation of corn fiber, cottonseed hulls, oat hulls and soybean hulls as roughage sources for ruminants. Journal of Animal Science, Savoy, v. 65, n. 1, p. 244-255, 1987.

JORGE, J. R. V.; ZEOULA, L. M.; PRADO, I. N.; GERON, L. J. V. Substituição do milho pela farinha de varredura (Manihot esculenta, Crantz) na ração de bezerros holandeses. Brazilian Journal of Animal Science, Viçosa, v. 31, n. 1, p. 192-204, 2002.

KAZAMA, R.; ZEOULA, L. M.; PRADO, I. N.; SILVA, D. C.; DUCATTI, T.; MATSUSHITA, M. Características quantitativas e qualitativas da carcaça de novilhas alimentadas com diferentes fontes energéticas em dietas à 
base de cascas de algodão e de soja. Brazilian Journal of Animal Science, Viçosa, v. 37, n. 2, p. 350-357, 2008.

MACEDO, L. M.; PRADO, I. M.; PRADO, J. M.; ROTTA, P. P.; PRADO, R. M.; SOUZA, N. E.; PRADO, I. N. Chemical composition and fatty acids profile of five carcass cuts of crossbred heifers finished in feedlot. Semina, Londrina, v. 29, n. 3, p. 599-610, 2008.

MAGALHÃES, K. A.; VALADARES FILHO, S. C.; PAULINO, M. F.; VALADARES, R. F. D.; PAULINO, P. V. R.; CHIZZOTTI, M. L.; PORTO, M. O.; MARCONDES, M. I.; ANDREATTA, K. Desempenho, composição física e características da carcaça de novilhos alimentados com diferentes níveis de casca de algodão, em confinamento. Brazilian Journal of Animal Science, Viçosa, v. 34, n. 6, p. 2466-2474, 2005.

MAGGIONI, D.; MARQUES, J. A.; PEROTTO, D.; ROTTA, P. P.; DUCATTI, T.; MATSUSHITA, M.; SILVA, R. R.; PRADO, I. N. Bermuda grass hay or sorghum silage with or without yeast addition on performance and carcass characteristics of crossbred young bulls finished in feedlot. Asian-Austaliasian Journal of Animal Science, Korea, v. 22, n. 2, p. 206-215, 2009.

MARQUES, J. A; PRADO, I. N.; ZEOULA, L. M.; ALCADE, C. R.; NASCIMENTO, W. G. Avaliação da mandioca e seus resíduos industriais em substituição ao milho no desempenho de novilhas confinadas. Brazilian Journal of Animal Science, Viçosa, v. 29, n. 5, p. 15281536, 2000.

MOREIRA, F. B.; SOUZA, N. E.; MATSUSHITA, M.; PRADO, I. N.; NASCIMENTO, W. G. Evaluation of carcass characteristics and meat chemical composition of Bos indicus and Bos Taurus crossbred steers finished in pasture systems. Brazilian Archives of Biology and Technology, Curitiba, v. 46, n. 4, p. 609-616, 2003.

NATIONAL RESEARCH COUNCIL - NRC. Nutrient requirement of beef cattle. 7. ed. Washington, D.C.: National Academic Press, 1996. 242 p.

OLTJEN, R. R.; DINIUS, D. A.; GOERING, H. K. Performance of steers fed crop residues supplemented with nonprotein nitrogen, minerals, protein and monensin. Journal of Animal Science, Savoy, v. 45, n. 6, p. 14421452, 1977.

PRADO, I. N.; ARICETTI, J. A.; ROTTA, P. P.; PRADO, R. M.; PEROTTO, D.; VISANTAINER, J. V.; MATSUSHITA, M. Carcass characteristics, chemical composition and fatty acid profile of the Longissimus muscle of bulls (Bos taurus indicus vs. Bos taurus taurus) finished in pasture systems. Asian-Australasian Journal of Animal Sciences, Korea, v. 21, n. 10, p. 1.449-1.457, 2008c.
PRADO, I. N.; BRANCO, A. F.; ZEOULA, L. M.; SAKAGUTI, E. S. Desempenho e características de carcaça de bovinos Nelore confinados, recebendo 10 ou $30 \%$ de caroço integral de algodão, bagaço auto hidrolisado de cana-de-açúcar e cana de açúcar ou capim elefante. Brazilian Archives of Biology and Technology, Curitiba, v. 38, n. 2, p. 353-365, 1995.

PRADO, I. N.; ITO, R. H.; PRADO, J. M.; PRADO, I. M.; ROTTA, P. P.; MATSUSHITA, M.; VISENTAINER, J. V.; SILVA, R. R. The influence of dietary soyabean and linseed on the chemical composition and fatty acid profile of the Longissimus muscle of feedlot-finished bulls. Journal of Animal and Feed Sciences, Jablona, v. 17, n. 3, p. 307-317, 2008d.

PRADO, I. N.; MARTINS, A. S.; ALCALDE, C. R.; ZEOULA, L. M., MARQUES, J. A. Desempenho de novilhas alimentadas com rações contendo milho ou casca de mandioca como fonte energética e farelo de algodão ou levedura como fonte protéica. Brazilian Journal of Animal Science, Viçosa, v. 29, n. 1, p. 278-287, 2000.

PRADO, I. N.; OLIVEIRA, A. N.; ROTTA, P. P.; PEROTTO, D.; PRADO, I. N.; SILVA, R. R.; SOUZA, N. E.; MOLETTA, J. L. Chemical composition and fatty acid profile in the Longissimus muscle of crossbred bulls. Asian-Australasian Journal of Animal Science, Korea, v. 22, n. 7, p. 1054-1059, 2009b.

PRADO, I. N.; PRADO, R. M.; ROTTA, P. P.; VISANTAINER, J. V.; MOLETTA, J. L.; PEROTTO, D. Carcass characteristics and chemical composition of the Longissimus muscle of crossbred (Bos taurus indicus vs Bos taurus taurus) finished in feedlot. Journal of Animal and Feed Sciences, Jablona, v. 17, n. 3, p. 295-306, $2008 \mathrm{a}$.

PRADO, I. N.; ROTTA, P. P.; PRADO, R. M.; VISANTAINER, J. V.; MOLETTA, J. L.; PEROTTO, D. Carcass characteristics and chemical composition of the Longissimus muscle of Purunã and $1 / 2$ Purunã vs. $1 / 2$ Canchin bulls. Asian-Australasian Journal of Animal Sciences, Korea, v. 21, n. 9, p. 1296-1302, 2008 b.

PRADO, I. N.; VISENTAINER, J. V.; ROTTA, P. P.; PEROTTO, D.; MOLETTA, J. L.; PRADO, R. M.; DUCATTI, T. The effect of breed on the chemical composition and fatty acid profile of the Longissimus dorsi muscle of Brazilian beef cattle. Journal of Animal. and Feed Sciences, Jablona, v. 18, n. 2, p. 231-240, $2009 \mathrm{c}$. 
PRADO, R. M.; PRADO, I. N.; MARQUES, J. A.; ROTTA, P. P.; VISENTAINER, J. V.; SILVA, R. R.; SOUZA, N. E. Meat quality of the Longissimus muscle of bulls and steers (1/2 Nellore vs. 1/2 Simmenthal) finished in feedlot. Journal of Animal and Feed Sciences, Jablona, v. 18, n. 2, p. 221-230, 2009a.

ROGERS, G. M.; POORE, M. H.; PASCHAL, J. C. Feeding cotton products to cattle. The Veterinary Clinics Food Animal Practice, Orlando, v. 18, n. 2, p. 267-294, 2002.

ROTTA, P.P.; PRADO, I. N.; PRADO, R. M.; MOLETTA, J. L.; SILVA, R. R.; PEROTTO, D. Carcass characteristics and chemical composition of the Longissimus muscle of Nellore, Caracu and Holstein-Friesian bulls finished in feedlot. Asian-Australasian Journal of Animal Science, Korea, v. 22, n. 4, p. 598-604, 2009a.
ROTTA, P. P.; PRADO, R. M.; PRADO, I. N.; VALERO, M. V.; VISENATINER, J. V.; SILVA, R. R. The effects of genetic groups, nutrition, finishing systems and gender of Brazilian cattle on carcass characteristics and beef composition and apperance: a review. Asian-Australasian Journal of Animal Science, Korea, v. 22, n. 12, p. 17181734, 2009b.

SAS INSTITUTE, SAS/STAT ${ }^{\circledR}$. User's guide: statistics, version 8.1. 4 ed. Cary: SAS Institute, 2000. v. 2.

SILVA, D. J.; QUEIROZ, A. C. Análise de alimentos métodos químicos ebiológicos. Viçosa, MG: Universidade Federal de Viçosa, 2002. 160 p.

VERNLUND, S. D.; HARRIS, B.; VAN HORN, H. H.; WILCOX, C. J. Effects of masonex and forms of cottonseed hulls on dairy cows. Journal of Dairy Science, Savoy, v. 63, n. 12, p. 2037-2043, 1980. 
